UDK $850.03-293=862$

\title{
AN EARLY CROAT TRANSLATION OF RINUCCINI'S "EURIDICE»
}

\author{
Bojan B u jić (Reading, England)
}

Some time ago Dragan Plamenac drew attention to the existence of an early 17th-century translation into Croat of Ottavio Rinuccini's Euridice, ${ }^{1}$ the text which served as the libretto for the first preserved opera, set to music by both Jacopo Peri and Giulio Caccini. Plamenac did not discuss the translation at any length since he rightly observed that wevery attempt to fit the Slavic text to the music that went with the Italian has failed of a practicable result. $\aleph^{2}$ Later the translation was briefly discussed by $D$. Pavlović in his study of the origins of musical theatre in Dubrovnik ${ }^{3}$ and his observations have recently been brought to light again by J. Andreis in his Music in Croatia. ${ }^{4}$ Having satisfied himself that there was no way in which Primović's Croat text could be fitted under the existing music of either Peri or Caccini, Plamenac presumably concluded, althought he nowhere says so explicitly, that Primovic simply translated the text of Ottavio Rinuccini's dramatic poem in the way in which a little later Ivan Gundulić, a person of much higher literary standing than Primović, translated the same author's Arianna. Pavlovic mentions the specific musical stage directions which appear in Primović's translation and these he sees as a sure indication that the translation was used in a performance with music. Andreas too mentions these stage directions, but both authors take them simply as examples of Primović's awareness of the role of music without tracing their origins. Apart from the obvious link with Rinuccini Primović's translation thus remains unconnected with its true sources and because it is only a small episode in the cultural history of a small nation, its significance for the early history of opera is likely to remain unrecognized.

The circumstances in which Rinuccini's Euridice was first set to music are too well known to be discussed here and therefore only a brief sum-

${ }^{1}$ D. Plamenac, Music of the 16th and 17 th Centuries in Dalmatia, Papers Read at the International Congress of Musicology Held at New York 1939, New York 1944, p. 34.

2 ibid.

${ }^{3}$ D. Pavlović, Melodrama $i$ počeci opere u starom Dubrovniku, Zbornik filozofskog fakulteta, II, Belgrade 1952, p. 249.

4 J. Andreis, Music in Croatia, Zagreb 1974, p. 50. 
mary will be offered..$^{5}$ Ottavio Rinuccini wrote his dramatic poem to be set to music and performed during the wedding festivities for Maria Medici and Henry IV of France. The performance took place on October 6, 1600 and the work which was heard was a joint effort of Peri and Caccini. In order to diminish the importance of Caccini's contribution and overshadow him, Peri had his version of the complete opera published, ${ }^{6}$ but vain and proud Caccini not to be outdone composed his own version of Euridice. ${ }^{7}$ The contest between two rival composers is therefore responsible for the existence of two printed scores and modern musical historiography has on those grounds attached a particular importance to Euridice, especially Peri's version which is hailed as being a better work than Caccini's although no serious assessment of the latter's work has ever been made. The original Peri-Caccini version was not heard again, but both of the rival scores were revived several times in the following fifteen years or so, one performance in Bologna preceding only by a year Primovićs Croat translation of $1617 .^{8}$

Pasko(j) Primović is still a relatively little known poet of the Dubrovnik school whose main interest seems to have been in translating and adapting works from other languages - s. Ljubić mentions his translations of psalms and hymn texts. ${ }^{9}$ His Euridice appeared in Venice in 1617 and although there is an indication that it is a translation, the authorship of Rinuccini is nowhere acknowledged. The full text of the title-page reads:

EVRIDICE / TRAGICOMEDIA / PASCE / PRIMOVICCHIA / LATINICCICHIA / DVBROVCIANINA / Prignesena po gnemu $u$ iesik Dubrovacki is / iesika Latinskoga. / Mnogo Svitlomu Gñu KRISTV Giliatovichiu / Potainiku Prisvitle Gospode samovladusctoga / Grada Dubrovnika. [Printer's mark.] Sctampana ù Bnezijeh Po Ivanu Salis. M.DC.XVII. / Superiorum permissu, et Priuilegijs. ${ }^{10}$

The dedicatory epistle that follows abounds in florid language and praises the dedicatee but does not throw any light on the destination of the translation or the reasons which prompted it.

${ }^{5}$ For a detailed account of the first performance of $"$ Euridice« see C. Palisca, The First Performance of "Euridice», Queen's College Department of Music Twenty-fifth Anniversary Festschrift, New York 1964, p. 1.

6 Le Musiche di Jacopo Peri Nobil Fiorentino Sopra l'Euridice Del Signor Ottavio Rinuccini..., Florence 1600 (1601).

${ }^{7}$ L'Euridice Composta in Musica in stille rappresentativo da Giulio Caccini detto Romano. Florence 1600 (1601).

${ }^{8}$ M. Schild, Die Musikdramen Ottavio Rinuccinis, Würzburg 1933, p. 40.

${ }^{\circ} \mathrm{S}$. Gliubich, Dizionario biografico degli uomini illustri della Dalmazia, Vienna 1856, p. 262.

10 "Euridice, a tragicomedy by Pasko Primović Latiničić of Dubrovnik. Translated by him from the Latin (Italian) language into the Dubrovnik (Croat) language. To the very illustrious Gentleman Kristo Giliatović. Secretary to the most illustrious Governors of the independent City of Dubrovnik. Printed in Venice By Ivan Salis. $1617 \ldots$... I have been able to trace two surviving copies. One, known to Plamenac is in the National University Library in Zagreb. It is slightly damaged, the last three pages are missing but the text has been added by hand, presumably that of A. Barichevich, one of its early owners, whose name appears on the titlepage. Another copy, in excellent condition, is in the British Library (formerly British Museum) in London. 
In common with other Dalmatian translators or adaptors of Latin and Italian plays Primovic gives some of the characters more homely Slavonic names so that compared with Rinuccini's original, Primović's list of characters looks as follows:

$\begin{array}{ll}\text { La Tragedia } & \text { (Omitted) } \\ \text { Euridice } & \text { Euridice } \\ \text { Orfeo } & \text { Orfeo } \\ \text { Arcetro } & \text { Radmio } \\ \text { Tirsi } & \text { Selenko } \\ \text { Aminta } & \text { Gliubmir } \\ \text { Dafne, nuntia } & \text { Dorka Vila Naviesniza } \\ \text { Venere } & \text { Venere } \\ \text { Coro di Ninfe e Pastori } & \text { Kor od pastira i od Vila } \\ \text { Plutone } & \text { Pluton } \\ \text { Proserpina } & \text { Proserpina } \\ \text { Radamanto } & \text { Radamanto } \\ \text { Caronte } & \text { Karonte } \\ \text { Coro di Ombre e Deita d'Inferno } & \text { Kor od pastira i od Vila }\end{array}$

It is the main protagonists who retain their names, the names of Arcadian shepherds and shepherdesses well established in the pastoral tradition of the sixteenth century are changed presumably in order to suggest more strongly the fanciful identification by Dubrovnik authors of the surroudings of their city with Arcadia.11

Primović completely omits La Tragedia and her prologue which figures so prominently in Rinuccini's original. This seems to suggest that Primovic had in mind a possible performance in Dubrovnik and that the translation was not only a literary exercise. The Prologue, though it aspires to represent the universal role of tragedy is a truly occasional piece which has to be understood against the background of the royal wedding for which the opera was written and performed. ${ }^{12}$ Words like:

\author{
Lungi via, lungi pur da regi tetti \\ Simolacri funesti, ombre d'affanni \\ Ecco i mesti coturni e i foschi panni \\ Cangio, e desto ne i cor più dolci affetti. ${ }^{13}$
}

11 This was made possible by the fortuitous fact that the name Dubrovnik is derived from dubrava - a wood. To be sure, at several points Primovic renders the word bosco as Dubrava and prints it with a capital letter.

${ }_{12}$ The implications of this have been recently discussed by Barbara Russano Hanning, Apologia pro Ottavio Rinuccini, Journal of the American Musicological Society, XXVI, 1973, p. 240.

${ }^{13}$ It may be convenient here to bring to light an early nineteenth-century translation into English:

Far, far be banish'd from the royal sight

Funereal forms and shadows of distress!

Lo! now the tragic buskin, mournful dress,

I change, and in the mind awake delight.

(Joseph Cooper Walker, Memoirs of Alessandro Tassoni... also an Appendix Containing Biographical Sketches of Ottavio Rinuccini, ... and an Inedited Poem of Torquato Tasso..., London 1815, p. 225.) 
and the reference to the "royal Seine» would have meant very little in Dubrovnik where there were no royal heads or hereditary rulers and where it was not customary to address the Rector, who was elected by the aristocratic parliament, by any glowing terms of praise. To be meaningful and acceptable within the conventions in Dubrovnik the prologue would have had to be reshaped so much that it would have been rendered virtually meaningless and Primovic must have realized the futility of such an undertaking.

In Rinuccini's printed libretto as well as in the scores of Peri and Caccini the division into acts is implied and is indicated through directions for the change of scene but the word wact" is not used anywhere. Primovic differs from all these sources in that he clearly marks the beginning of each act and refers to each with the Croatized word At. Stage directions are most frequent in the first act, and the whole text is laid out clearly and with ample spacing, the name of the character appears in the middle of the page, above the appropriate lines, like this:

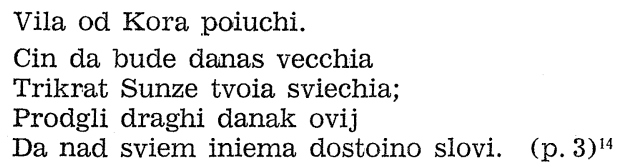

In the rest of the text (acts 2-5) the names of the characters are printed in smaller type and in abbreviated form, next to the first line to which they refer, similar to the way in which they were printed in the first edition of the original libretto of 1600 :

Rad.

Blascena Gluibav bud, i gne stril tai slati

Cemerni ka tvoi trud, ù rados obrati (p. 14)

This may have been done in order to save space and reduce the number of pages. References to music are also less frequent after the first act.

It is these references to music, especially in the first act, that have intrigued Plamenac, Pavlović and Andreis. Where did Primović get them from? Certainly not from Rinuccini's libretto where not a single reference to music appears. Also, in the published version of the libretto Rinuccini follows the logical flow of the text and thus avoids repetitions which are inevitable if an operatic ensemble scene has to be fashioned out of a single line of text once the libretto is set to music. Compared to the original, Primović's version reads quite convincingly as an accurate record of the action as it develops in sung form. A sentence once spoken by one character is repeated by another, then again by the original one, then the same words are given to the choir. Such deployment makes no sense in a spoken play but makes perfect sense if the words are sung. It is therefore natural to refer to one of the early settings of Euridice and the better known Peri's version is the obvious first choice. At the start of his first act Peri closely

\footnotetext{
14 Primovic's original spelling has been retained throughout. The only exceptions are the intervocalic $u$ which has been changed into $v$, and in some cases the inicipient $v$ followed by a consonant, which has been changed into $u$ (e.g. Svarsciuie - Svarscivie; Vsdarscite - Usdarscite).
} 
follows Rinuccini's original where the sequence of speakers is: Coro (which in this case means "the leader of the choiru), Ninf(a), Past(ore), Ninf(a). This second time Nymph sings the following words:

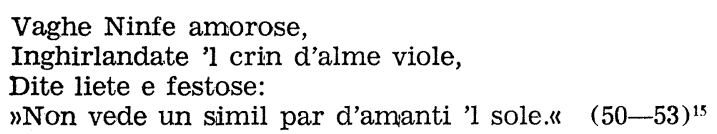

It is at this point, when Rinuccini, following the habit of so many Italian Petrarchist, pays hommage to Petrarch by quoting him, ${ }^{16}$ that Peri constructs the first ensemble scene of the opera: Petrarch's line is repeated first by a Pastore del Coro, then by Arcetro and then sung by five-part choir. Primovic follows this order, in outline at least, and it may appear that he took Peri as a model and introduced two minor changes: instead of Arcetro it is again the Nymph who repeats Petrarch's line and the choir is described as singing in four parts (Kor ù cetiri glasa) instead of Peri's five. However, a simple comparison with Caccini's Euridice clearly reveals Primovićs source: it is there that the Nymph sings the line given by Peri to Arcetro, and the choir at the end is, indeed, in four parts. ${ }^{17}$ This is an exciting detail for not only does it make Primović's Euridice the earliest translation of an operatic libretto from Italian into another language, but also seems to indicate that the translation was done from the score of Caccini rather than from Rinuccini's libretto as has hitherto been assumed. The whole of Primović's first act can be easily related to Caccini's score. True, the very first reference to music at the beginning of the translation: Pastir od Kora Parvi poiucchi ù sam glas ("The first shepherd from the choir singing alone") is Primovićs addition which does not appear in any of the Italian sources but describes what actually happens in a performance. After the first ensemble scene where the link between Primovic and Caccini is obvious there follows a short dialogue between a shepherd and Euridice, followed in turn by the final ensemble in which the solos of Nymphs and shepherds are punctuated by the ritornello $A l$ canto al ballo sung by the choir. At this point Peri's score reads simply: Partesi Euridice, $e$ Dafne con altre Ninfe del Coro. Caccini's score gives a more precise indication: Coro Primo a V e si replica al fine d'ogni stanza. Al canto al ballo, to which closely corresponds Primović's Kor parvi ù pet glasa. Na tanze na piesni. Rather than simply indicating that the ritornello should be repeated after each stanza as is done by Caccini, Primovic prints the repetition in full, presenting an account of what happens when the score is sung.

It is quite natural to expect that the rest of Primović's translation conforms with Caccini in the same manner. Unfortunately this is not the case

15 Numbers in brackets after quotations from Rinuccini refer to the lines as marked in the edition by Angelo Solerti, Gli arbori del melodrama, Milan 1904-5, Vol. II, pp. 105-152.

${ }^{16}$ Non vede un simil par d'amanti ' $l$ sole is the ninth line of Petrarch's sonnet Due rose fresche e colte in paradiso (Rerum vulgarium fragmenta, CCXLV) and the whole scene of Rinuccini may be seen as a gloss on the pastoral connotation of the sonnet.

${ }_{17}$ See Appendix for the full comparison of the three versions. 
and the question of Primovićs sources for the rest of the libretto becomes a puzzling one. This can be ilustrated by comparing Primović's layout and stage directions with those in the two scores.

\section{Second act}

1. The first stage direction in act two: Selenko ishodij slijrom, ter poie and Isti Priblisciavascise k'Orfeu sliedi poiuchi (p. 16) way have been modelled on Peri's Tirsi viene in scena sonando la presente Zinfonia con un triflauto, e canta la seguente stanza: salutando Orfeo di poi s'accompagna con gli altri del Coro, e con tale stromento fu sonata. (preceding Rinuccini 144). At this point Caccini's score has no stage direction at all.

2. Primović's stage direction Kor od Vila vrachiase skladenza is closer to Peri's Ninfa del coro. Qui tornano le compagne di Euridice con Aminta, than to Caccini's Ninfa del coro, although Primović does not follow Peri's subsequent slight alterations of Rinuccini's text.18

\section{Third act}

One of Rinuccini's rare stage directions occurs at the end of the act: Qui il Coro parte, e la scena si tramuta. Caccini alters this only slightly: $E$ qui il Coro si parte, e si tramuta la scena, whereas there is a connection between Peri's Coro si parte, e la Scena si muta in Inferno and Primović's Promieniuiese Scena; $i$ Kasciuse Strane paklene (p. 34).

Fourth act

1. Having led Orfeo into the underworld Venus disappears. Primović's Veneremu gine s'ociu, a on ostaie sam ter us lijru poie (p. 36) corresponds to Peri's Venere si parte, e lascia Orfeo nell'Inferno, whereas Caccini has no stage direction at this point.

2. At the beginning of the closing scene Primovićs Kor od Boscianstva Paklenieh Parvi is closer to both Rinuccini's Coro di Ombre e Deità d'Inferno (preceding 554) and Peri's Dietà d'Inferno. Primo coro a 4, than it is to Caccini's Coro Quarto a 4. Primo coro.

There are no stage directions in Primović's fifth act and the closing text of the choir is given in straight form as it appears in Rinuccini, without any reflection of the repetitions occasioned by the setting.

The supposition that Primovic used Caccini's version for the first act and Peri's for the remaining four must be discounted straight away. Peri does not follow the libretto literally but at a number of points deviates from it either by giving Rinuccini's original words to persons other than those marked in the libretto, or inserts fragments which do not appear in Rinuccini. In all such cases Primović, like Caccini, closely follows Rinuccini's version.

Peri's insertions are not uniteresting in themselves. Between lines 172 and 173 (Arceto, followed by Orfeo) we find:

${ }^{18}$ Wherever in this section Peri deviates from Rinuccini, Primovic follows Rinuccini. If Caccini alters Rinuccini Primovic follows Caccini. Thus at 265 original libretto and Peri read: Choro. Cruda morte .. Caccini: Ninfa del Coro, e comincia il coro 2. Cruda morte... whom Primović follows with Vila od Kora. Dali moscesc huda smarti... 
Dafne: O giorno pien d'angoscia e pien di guai.

and between lines 604 and 605 (Choro followed by Aminta), he gives additional words to Amita:

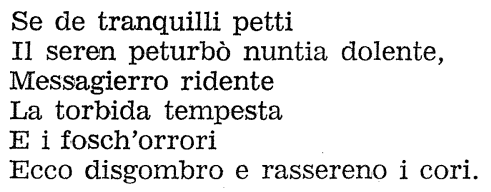

It is possible that these insertions are by Peri himself. The first one has a certain Petrarchan flavour and it is perhaps not too fanciful to suggest that the words are modelled on the last line of Sonnet CCXLV:: o felice eloquentia, a lieto giorno! This is the very same sonnet from which Rinuccini had already quoted. By reversing the meaning Peri demonstrates that the state of joy, earlier connected with the quotation from Petrarch is now transformed into a tragic situation, and also provides a point of reference which the public versed in refined poetic allusions would have been able to recognize. Similarly, Aminta later announces that the tragedy is over and sees himself as a joyous counterpart to the tragic messenger, Dafne. Also, it is not difficult to observe a connection between Aminta's words and the third stanza of the Prologue. ${ }^{19}$

In the absence of any libretto which would combine the features of Peri's and Caccini's version of the opera in the way in which it was done in our translation, Primović's source remains obscure. The connection between Caccini's and Primovićs is too close to be ascribed to a mere coincidence and the insertion of stage directions which cannot be found in Rinuccini indicates that he could not have relied only on the original libretto for those acts. He may have started to translate from Caccini's score, but having found that impractical switched to a libretto, now lost, based on Rinuccini's original and prepared, with stage directions for the Bologna performance of Peri's version in 1616. This is seemingly the only way in which Primovićs inconsistencies and the change of layout between the first act and the rest of the text could be explained. To the best of our knowledge there is no record of a libretto issued for the Bologna performance. Also, it is not known whether Primovic was indeed in Bologna in that year but his translation bears a strong mark of an eyewitness account. At the opening of his translation he states that the First Shepherd sings alone. Later he refers to Selenko (Tirsi) as »coming out with a lyre» (Selenko ishodij slijrom ..., p. 16) and to Orfeo saccompanying himself on a lyre« (ter us lijru poie, p. 36), both precise descriptions not found in any other source, which could have been prompted by his recollection of an actual staging.

It is temping to speculate how aware Primovic was of the significance of various cultural forces which determined the ideology of the Cameratists. Florentine Neoplatonism, symbolic tradition of the intermedi, Mannerism, and the Aristotelianism of Girolamo Mei each of which exerted

${ }^{19}$ See above p. 18. 
some influence on the early opera were not so strongly in evidence in the culture of Dubrovnik from which he stemmed. Now it is true that Petrarchism profoundly influenced Dalmatian and Dubrovnik poetry of the sixteenth century, but the poetic diction which emerged there was not the diction of slavish and uninventive imitators. Dalmatian authors succeeded in blending standard Petrarchan elements with patterns and conventions of the popular poetic tradition. In the process the density and richness of Petrarchan language were somewhat diluted to bring it closer to the eloquence and certain narrative quality which characterizes folk poetry. Fifteenth and sixteenth-century translators of Petrarch such as Šiško Menčetic or the Zadar poet Petar Zoranić regularly lengthened Petrarch's line and hardly ever kept to the prescribed number of lines in a sonnet - in their hands sonnets became poems of sixteen ilnes. Primovic inherited this technique from the sixteenth-century Petrarchists and applied it to Rinuccini's verses. Although at a number of places he shortens Rinuccini's text by omitting odd lines, his general tendency is to lengthen. Examples such as the following, where in a longer fragment the number of lines in the translation corresponds to that of the original are rare and the correspondence is usually achieved through condensing the text of the original:

Rinuccini (162-169)

Dafne:

Primović (p. 17)

Lassa! che di spavento e di pietate

Dorka Vila Naviesniza:

Gelami il cor nel seno!

Miserabil beltate,

Iaoh, od straha, i scialosti

Sarzeseie me sledilo;

Come in un punto, ohimè! venisti meno. Dalis u cias potamnilo?

Ahi! che lampo o baleno

In notturno seren ben ratto fugge,

Ma più rapida l'ale

Affretta umana vita al đì fatale.

Vai, kom nochnò mugna sijne

Naghlò utece, i poghine;

Ali gliudzki scivot prece

Ksughienomu dnevi tece.

Rinuccini's poem is written predominantly in lines of seven and eleven syllables, as was the case with a great deal of poesia per musica of that time, and these Primovic in most cases attempts to render into octosyllabic lines often forming a rhyming couplet:

Rinuccini (189)

Primović (p. 19)

Orfeo:

Orfeo:

Ah! non sospender più l'alma dubbiosa.

Rezi Vilo, rezi sctoie

Ier trepti, i cesne sve sarze moie.

Such renderings often sound simple and naive but are examples of a clear tendency to bring Rinuccini's text firmly into the Dalmatian poetic tradition. Alexandrian lines form another part of that tradition and indeed, Primovic from time to time unexpectedly changes from octosyllabic lines to the dodecasyllabic ones:

Rinnucini (716-718)

Orfeo:

La bella Dea d'Amore,

Non so per qual sentiero,

Scorsemi di Pluton nel vasto impero.
Primović (p. 59)

Orfeo:

Slavname odvede, Matti od Gliubavi

Tere me povede, ù pakao, i stavi. 
No special musical significance should be sought in such instance. It is true that in mid-seventeenth-century Venetian libretti, like those by Giovanni Faustini written for Cavalli, different lengths of lines were beginning to indicate the emerging difference between the recitative and aria but this could hardly be expected at the time of Primovićs translation. He was simply following the native tradition and made his Euridice almost a compendium of devices and patterns cultivated by Dalmatian authors.

Versification was not the only problem involving two cultures with which Primovic had to deal. Behind Rinuccini's text stands the weight of tradition and convention which had accumulated over decades of intense activity in devising textual contrapposti, in staging the intermedi, in inventing symbolic images in which the power of music would be illustrated through references to the celestial spheres and the influence of celestial music on human character and behaviour. Audiences expected these things and the audience of Rinuccini's Euridice contained enough refined and cultivated people for, among other things, subtle references to Petrarch not to be wasted. Primovic by comparison had little to what to relate in the theatrical tradition of Dubrovnik. True, the tradition of pastoral play had been strong there but it did not include the learned and the symbolic elements. Is is not surprising, therefore, to find that in a particular place where Rinuccini alludes to the symbolic implications of celestial harmony, Primovic's translation omits the allusion and changes the tone of the passage:

Rinuccini (384-389)

Al rotar del ciel superno Non pur l'aer e 'l foco intorno, Ma si volve il tutto in giro: Non è il ben nè 'l pianto eterno; Come or sorge, or cade il giorno, Regna qui gioia o martiro.

\author{
Primović (p. 33) \\ Nisctor nie viekovito, \\ Minuchiesu stvari svijme; \\ Sad nesrechno, sad cestito \\ Na svituse traie brime, \\ Sctose rodij sve umira. \\ Sunze istece, pak sapade, \\ Svitlos dnevi noch vasima; \\ $\mathrm{Na}$ tem svitu (vai) nikade \\ Nitko stavna dobra neima; \\ Srechie ovdi prave nie..$^{20}$
}

Primović thus gives his version a stronger moralistic stamp. Of course there are moralistic overtones throughout Rinuccini's poem, but introduced in such a way as not to detract from the flow and the flavour of the drama. Primović, however, attaches some importance to such places and, as in the above examples, lengthens the text in translation to secure the impact. It is not only the difference of the two traditions: the few years that divide Rinuccini, with his firm roots in the sixteenth century, from the translation saw a marked increase in the prominence given to the moralistic tendencies of the Counter-Reformation and these Primović's work exhibits more consiously. In Primovićs version Christian terminology sometimes substi-

20 Nothing is eternal, / Everything has its time / Now tragic now good / Time passes in this world / whatever is born dies in the end. / The sun rises and sets, / Night takes away the light of day: / In this world (alas) nobody knows / of constant good; / Here there is no happiness. 
tutes what had in the original still been terminology appropriate for a pagan religion. Benigno don de gl'immortali Dei (298) becomes Darov saisto Priviscgnega (p. 26), Priviscgni being an expression for the Almighty. Quando al tempio andaste (639) is rendered as $K$ svetoisi ter Zarkvi... (p. 53). The wholy church" thus significantly reinforces the neutral tempio of the original.

On the basis of the given examples it should not be assumed that Primovic is quite insensitive to the implications of Rinuccini's text. In a number of other instances his translation is faithful and accurate in detail, the changes he introduces are only the matter of stress and not of a thorough alternation of Rinuccini. One of the very important aspects of Rinuccini's work is preserved by Primovic and confirms that he was aware of an element of large-scale construction which modern readers of the libretto, or listeners to the operas, divorced from the intellectual climate in which the works were created, are likely to overlook.

An important element of the early opera was the desire, not unconnected with the Mannerist preoccupation with the idea of time and change as constructive elements, to represent human passion and suffering through music, but not in a descriptive form as had been done in the madrigal but in actual sense - to make the audience aware of the passage of time during which the protagonists of the opera experience through music their passion, suffering and redemption..$^{21}$ One structural device used in order to bring this more forcefully to the attention of the audience was Peri's insertion of the antithesis to the quotation from Petrarch and later explicit statement of Aminta in which the audience is reminded that the tragic story, having run its full course, brings us back to the state of bliss. That state of bliss is reached through the magic power of Orfeo's music and its attainment is, as we shall see, also coupled with an ingenious device borrowed again from the Mannariest repertoire.

Orfeo is a demigod (semideo) associated with music and love, and it is Venus who is especially invoked by the chorus at the end of the first scene:

Rinuccini (93-96)

Bella Madre d'Amor, da l'alto coro Scendi a' nostri diletti,

$\mathrm{E}$ co' bei pargoletti

Fendi le nubi e 'l ciel con l'ali d'oro

\author{
Primović (p. 10) \\ Slavna mati od Gliubavi, \\ Kas raiskoga punna uresa \\ Sijdi knami, ter ostavi \\ Tvoi stan tretieh varh nebesa; \\ Svitla krijla tva rasciri, \\ Stavnò siedin' i samiri \\ Ugliubavi po sve vike \\ Ove slavne gliubovnike.
}

It is she who again comes to Orfeo's rescue, as Aminta tells us in the third scene. Without ever mentioning her name he gives an attribute of Venus - chariot pulled by doves:

${ }^{21}$ See R. E. Wolf, The Aesthetic Problem of the "Renaissance», Revue Belge de Musicologie, IX, 1.955, p. 83. 
Rinuccini (345-353)

Allor gli occhi repente

Rivolsi al folgorar del nuovo lume, $\mathrm{E}$, sovr'uman costume,

Entro bel carro di zaffir lucente

Donna vidi celeste, al cui sembiante

Si coloriva il ciel di luce e d'oro;

Avvinte al carro avante

Spargean le penne candidette e snelle

Due colombe gemelle,
Primović (p. 30)

Satiemmise vijd otvori;

Tui samierih gdi oholla

Raiska lipos sijde sgori

Varh svietlusctih ciudnieh kolla.

Vidieh slavna tad ciudesa

Gdi nebesko ono lize,

Svit resiasce, i nebesa

Ili Vile, il Boscize.

Svitla kolla dvie ptize

Bieglie sniega potesahu;

A toi biehu golubize;

Bielochiomse kę diciahu.

Venus then leads Orfeo towards the underworld and tells him to proceed further alone in order to try and influence Pluto to release Euridice:

Rinuccini (415-418)

Prega, sospira e plora:

Forse avverà che quel soave pianto

Che mosso ha il Ciel, pieghi l'Inferno ancora.
Primović (p. 36)

Placi, usdisci, zvili, moli; Ier kad nebo ktiete ciuti, Ter natvoi plac sijde doli I Pakao chiesc moch prighnuti.

At the end of the play the Chorus (Aminta) confirms that indeed Orfeo was able to do this throught the power of his lyre:

Rinuccini (731-742)

Felice Semideo, ben degna prole Di lui che se ne l'alto

Per celeste sentier rivolge il sole, Rompersi d'ogni pietra il duro smalto Vidi a' tuoi dolci accenti,

E 'l corso rallentar fiumi e torrenti, $\mathrm{E}$ per udir vicini

Scender da gli alti monti abeti e pini;

Ma vie più degno vanto oggi s'ammira

De la famosa lira,

Vanto di pregio eterno,

Mover gli Dei del ciel, piegar l'Inferno.

\author{
Primovic (p. 60) \\ Tij nai srechnij, i cestitij \\ Moscse svati sam saistinu \\ O Sunciani pravij sinu, \\ Vriedni, ciasni, plemeniti. \\ $\mathrm{Na}$ glas tvoijeh skladnieh piesni \\ Vidieh stvar ia velike, \\ Ustavgliatse barse rike \\ Skrachiatise sle boliesni: \\ Raspuzatse tvardi kami \\ Koriepit se dubia, i iele, \\ Ali ciuda vechia vele \\ Danas kase kasciu nami. \\ Ter koiasu toi ciudesa? \\ Romon slatke tvoie lijre, \\ Kij se slavno svud prostire, \\ Prighnut pakao, i nebesa.
}

Mannerist art in general, and literature in particular, relies on the effective and often unexpected unity of opposites, mostly expressed in a very concentrated form. Petrarch is often taken as a model and his piangendo rido may be considered a classical example of such unity, which since it implies putting together diverse and contradictory words, visual representations or shapes, was aptly named contrapposto.22 The whole text of Rinuccini, if viewed from this angle may be now seen as a giant contrapposto but stretched out across so large a time-scale to be almost ineffective. Orfeo, the musician in whose art is reflected the harmony of the celestial spheres wins as his ally Venus, "the daughter of the third heaven" as Pri-

${ }^{22}$ For a discussion of the characteristic Mannerist forms see John Shearman, Mannerism, Harmondsworth 1963, p. $81 \mathrm{f}$. 
movic tells us,23 and then regains for himself Euridice who had been claimed by the underworld; he manages to bring together two opposites: Heaven and Hades and Rinuccini's words piegar d'Inferno forcefully illustrate in terms of an image the deed which Orfeo accomplishes.

It is not uncommon to find that towards the closing stages of a stylistic period dimensions of works of art grow, the final flourish is often a display of abundance and complexity and it could be argued that Rinuccini's Euridice stands as one of the last examples of a literary tradition rooted in the Mannerist phase of the Italian Renaissance. By projecting a contrapposto on such a large canvas Rinuccini weakened its effect and made it almost disappear. It is nevertheless there as a reminder of yet another Mannerist attitude, that of difficultà, a deliberate complexity, difficulty, which a work of art has to possess in order to be judged as worthy and successful. The involvement of the audience through surmounting the difficultà becomes that way more intense and the listener is drawn more closely into a situation where he himself may experience the purifying effect of the tragic situation and its final happy turn. ${ }^{24}$ It is a credit to Primovic that he faithfully translated precisely these structurally important sections thus showing that he may have been aware of the less obvious implications of the original. We may never be able to discover whether his translation was set to music and performed - in itself it is a fascinating document of the interaction of the two cultures on the two sides of the Adriatic.

${ }^{23}$ At this point Primović perhaps echoes Boccaccio: "De secunda Venere Caeli septima filia et madre Cupidinis. Venerem secundam plures Caeli volunt fuisse filiam: ... (Genealogia deorum gentilium, Lib. III, Cap. XXIII).

${ }^{24}$ On difficultà and its connection with virtù see Shearman, ibid., p. 21. 


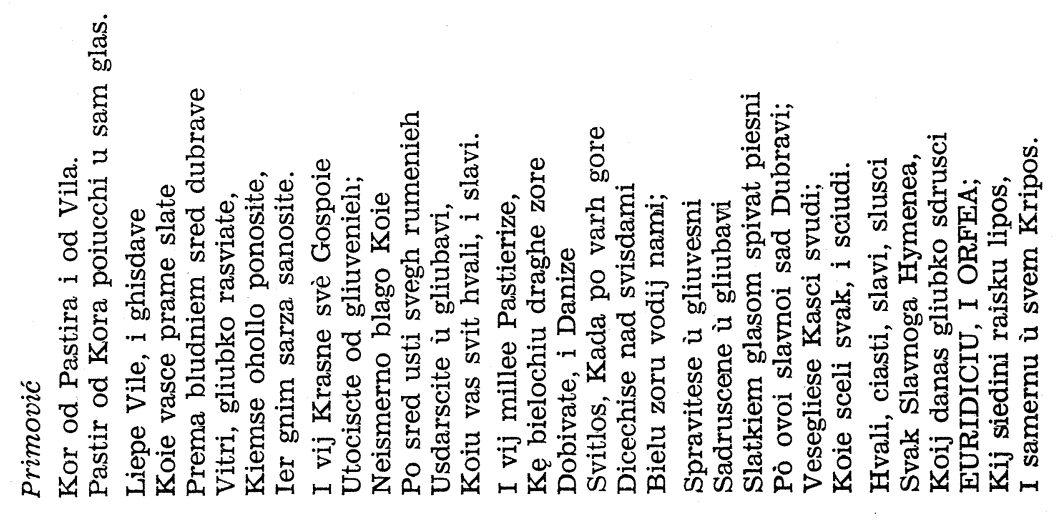

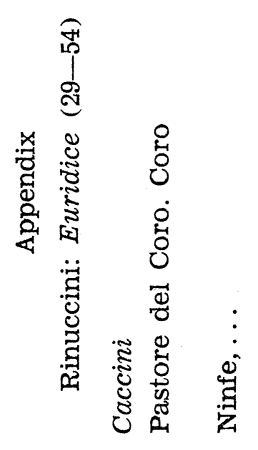

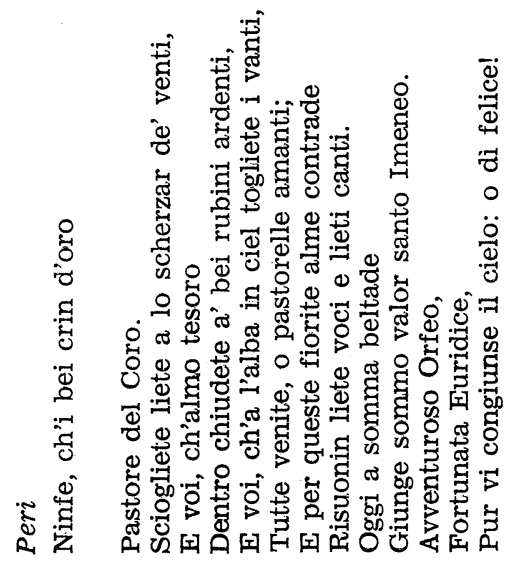




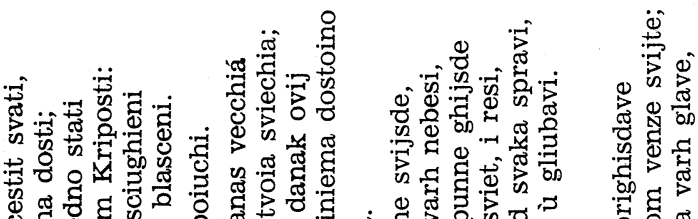

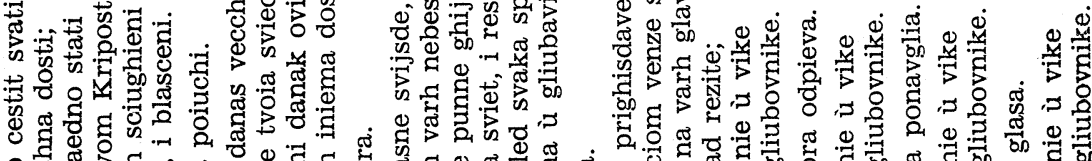

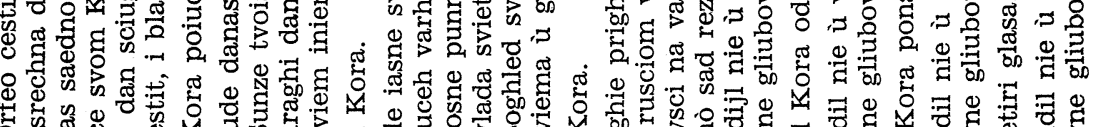

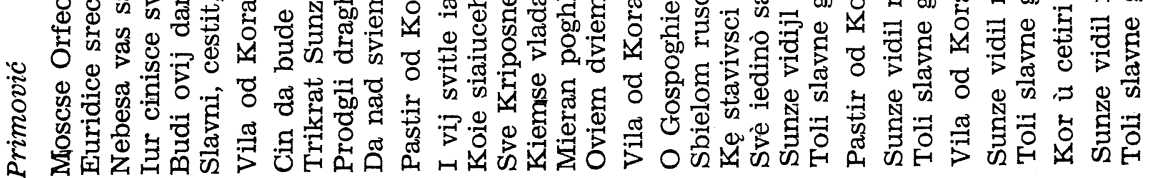

¿ू్

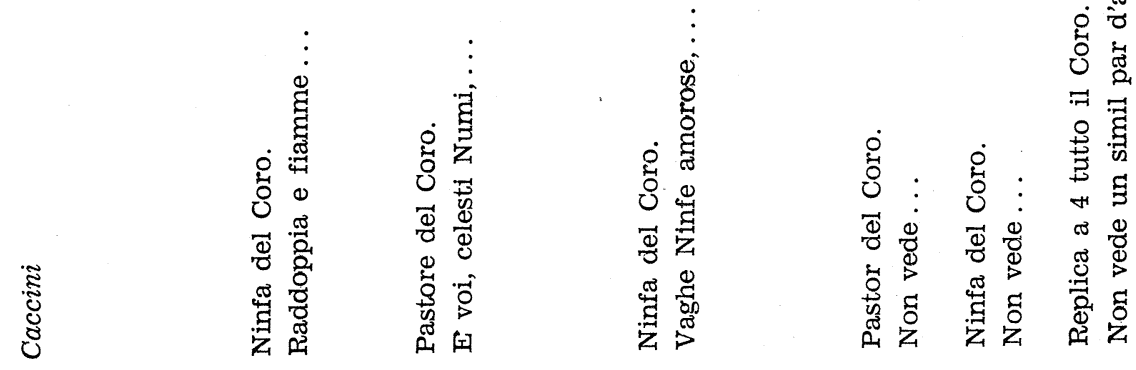

نे 7

0
$\tilde{q}$
$\tilde{a}$

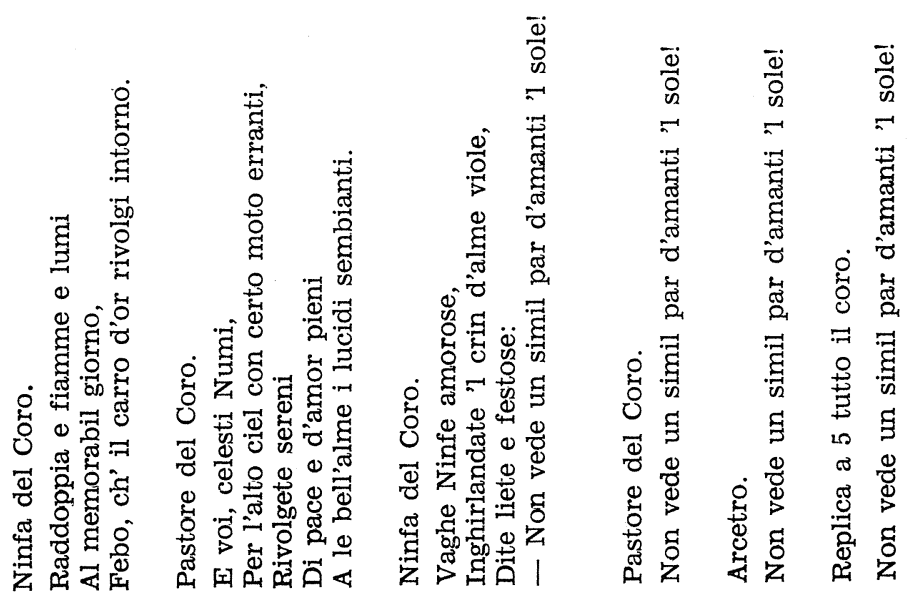




\section{POVZETEK}

Že pred nekaj časa je Dragan Plamenac opozoril na prevod Rinuccinijeve Euridice, libreta prve v celoti ohranjene opere Jacopa Perija in Giulija Caccinija. Prevod, ki je bil objavljen v Benetkah leta $1617 \mathrm{z}$ naslovom Euridice Tragicomedia Pasce Primovicchia Latiniccichia Dubrovcianina Prignesena po gnemu $u$ iesik Dubrovacki iz iesika Latinskog, vsebuje številna scenska navodila, med katerimi se omenja tudi glasba. Zato pojmujejo zgodovinarji gledališča in glasbe (D. Pavlović, J. Andreis) ta navodila kot indikacijo, da je bil Primovićev prevod namenjen za izvedbo $\mathbf{z}$ glasbo. Prevod ne sledi neprekinjenemu toku Rinuccinijeve pesnitve, ampak prinaša zlasti $\mathrm{v}$ ansambelskih prizorih dosti tekstovnih ponovitev, ki izgube smisel, če tekst beremo ali igramo brez glasbe, a ga seveda obdržijo pri petju. Primerjava $\mathrm{z}$ dvema verzijama opere, $\mathrm{s}$ Perijevo in Caccinijevo, pokaže, da Primović ni vzel originalnega Rinuccijevega besedila, ampak besedilo partiture ene in druge opere. Najbolj verjetno je, da je Caccinijeva verzija služila Primoviću za celotno prvo dejanje opere, medtem ko vsebujejo ostala štiri dejanja elemente obeh verzij.

Primović si prizadeva prilagoditi Rinuccinijevo verzifikacijo poetski tradiciji, ki se je formirala $v$ dalmatinski književnosti v 16. stoletju. Dalmatinski prevajalci Petrarke in italijanske lirike 16. stoletja opuščajo koncentrirano bogastvo Petrarkovega izraza $\mathrm{v}$ korist bolj narativnega stila, ki vsebuje elemente popularne in ljudske poezije. Tako Primović, razen tega da oblikuje svoj prevod v osmercih in dvanajstercih, ki so značilni za hrvaško poezijo, tudi pogosto razvija in razširja besedilo Rinuccinijevega izvirnika. Moralistične tendence protireformacije so očitne $\mathrm{v}$ Primovićevem tekstu. Izrazi in fraze, karakteristične za takšno arkadijsko pogansko religijo, kot jo je pojmovala italijanska renesansa 16 . stoletja, so $\mathrm{v}$ prevodu spremenjeni in tako občasno čutimo približevanje krščanski simboliki. To pa je povsem razumljivo, če vemo, da so Rinuccinijeve duhovne korenine $\mathrm{v}$ italijanskem 16. stoletju, medtem ko se je $\mathrm{v}$ sedemnajstih letih, ki dele Primovićev prevod od izvirnika, protireformacijsko gibanje v Dalmaciji močno okrepilo. Seveda pa se ne sme misliti, da Primović ni imel občutka za nekatere rafinirane maniristične efekte, ki jih je Rinuccini hotel doseči $\mathrm{v}$ besedilu svoje Euridice. Ob naslonitvi na maniristične težnje izkoriščanja efekta imenovanega contraposto, pri katerem prihajajo $\mathrm{v}$ neposredno zvezo na videz nezdružljiva nasprotja, postane Rinuccinijev Orfeo simbolična figura, ki z močjo svoje glasbe združuje nebesa in podzemeljski svet. Da bi usmeril poslušalčevo pozornost na ta efekt, poudarja Rinuccini od časa do časa $\mathrm{v}$ libretu nekatere od njegovih sestavnih delov, Primovićev prevod pa na niti enem od teh izrazitih mest ne odstopa od jasnosti originala.

Celoten Primovićev tekst je daljši od izvirnika in kot je že ugotovil Plamenac, $\mathrm{v}$ nobenem primeru ni mogel biti uporabljen za prvotno glasbo. Vendar ostaja neznano, ali je bilo to besedilo kdaj izvedeno $\mathrm{s}$ kakšno drugo glasbo. V vsakem primeru je to najstarejši prevod ne le nekega libreta, ampak tudi operne partiture iz italijanščine $\mathrm{v}$ drug jezik in $\mathrm{mu}$ zato gre tudi glede na to izjemno mesto $\mathrm{v}$ zgodnji zgodovini opere. 